\title{
PENGEMBANGAN MODEL INVESTIGASI SOIAL PADA PEMBELAJARAN MENULIS TEKS LAPORAN HASIL OBSERVASI BERKONTEKS KEARIFAN LOKAL PADA SISWA KELAS VIII SMP/MTS DI KABUPATEN BREBES
}

\author{
Hany Uswatun Nisa \\ Prodi Pendidikan Bahasa dan Sastra Indonesia, Fakultas Keguruan dan Ilmu Pendidikan, \\ Universitas Muhadi Setiabudi Brebes, Indonesia \\ E-mail: hanyuswatunnisa@gmail.com
}

\begin{abstract}
ABSTRAK
Penelitian ini bertujuan untuk mengidentifikasi kebutuhan pengembangan model investigasi sosial, memaparkan karakteristik model investigasi sosial, dan mengembangangkan serta menguji kefektifan model dalam skala terbatas. Muatan kearifan lokal diberikan guna untuk menggugah peserta didik agar mencintai budayanya. Penelitian ini menggunakan desain penelitian pengembangan $(R \& D)$ dari Borg and Gall. Langkah penelitian Borg and Gall diadaptasi menjadi tiga tahap, yakni penelitian, pengembangan, dan pengujian. Hasil penelitian ini didasarkan pada hasil angket kebutuhan pengembangan model menurut persepsi guru dan peserta didik, selanjutnya disusun berdasarkan karakteristik pengembangan model. Karakteristik tersebut meliputi pembelajaran yang kontekstual, pembelajaran berbasis masalah, pembelajaran dilakukan melalui interaksi sosial, dan pembelajaran yang memberikan kebebasan untuk memilih. Hasil uji keefektifan yang dilakukan di kelas VIII SMP N 1 Ketanggungan Brebes menunjukkan ada peningkatan nilai rata-rata pretes dan postes. Uji t pada sekolah tersebut sebesar 10,653, uji t pada kelas VIII MTS Subulul Ikhsan sebesar 10,986, dan uji t pada kelas VIII SMP N 2 Banjarharjo Brebes sebesar 7,785. Hal tersebut membuktikan adanya perbedaan yang signifikan terhadap penggunaan model investigasi sosial pada pembelajaran menulis teks laporan hasilobservasi berkonteks kearifan lokal.

Kata Kunci: Model Investigasi Sosial, Menulis Teks Laporan Hasil Observasi, Kearifan Lokal

Abstract

This study aims to identify the need to develop a social investigation model, explain the characteristics of the social investigation model, and develop and test the effectiveness of the model on a limited scale. The contents of local wisdom are given in order to inspire students to love their culture. This study uses a research and development $(R \& D)$ design from Borg and Gall. The Borg and Gall research step was adapted into three stages, namely research, development and testing. The results of this study are based on the results of the questionnaire needs to develop the model according to the perceptions of teachers and students, then arranged based on the characteristics of model development. These characteristics include contextual learning, problem based learning, learning done through social interaction, and learning that gives freedom to choose. The results of the effectiveness test conducted in class VIII SMP $N 1$ Ketebungan Brebes showed an increase in the average value of pretest and posttest. The t-test for the school was 10.653, the t-test for VIII MTS Subulul Ikhsan was 10.986, and the t-test for VIII grade at SMP N 2 Banjarharjo Brebes was 7.785. This proves that there is a significant difference in the use of social investigation models in learning to write report texts on the results of observations of local wisdom.
\end{abstract}

Keywords: Social Investigation Model, Writing Observation Report Text, Local Wisdom. 


\section{PENDAHULUAN}

Bahasa Indonesia telah menjadi sarana komunikasi yang sangat penting dalam kehidupan sehari-hari. Pada jenjang SMP/MTs pembelajaran menulis merupakan bagian yang tak terpisahkan dalam pembelajaran bahasa Indonesia. Tujuannya adalah agar siswa (1) mampu menuangkan pengalaman dan gagasan, (2) mampu mengungkapkan perasaan secara tertulis, (3) mampu mengungkapkan informasi sesuai dengan konteks dan keadaan, (4) peka terhadap lingkungan dan mampu mengungkapkannya dalam karangan, dan (5) memiliki kegemaran menulis untuk meningkatkan pengetahuan dan memanfaatkannya dalam kehidupan sehari-hari [1]. Apabila diajarkan secara efektif, kompetensi ini bermanfaat bagi siswa menjadi lebih produktif, aktif, kreatif, mendorong pribadi lebih maju, dan meningkatkan mutu hidup lebih bermakna.

Keterampilan menulis merupakan salah satu keterampilan berbahasa yang sangat penting untuk menunjang bagaimana berkomunikasi dengan baik dan benar kepada seseorang, khususnya dalam komunikasi tulisan.

Teks hasil observasi merupakan salah satu materi ajar yang dapat meningkatkan keterampilan menulis siswa. Teks hasil observasi merupakan suatu bentuk laporan dari hasil pengamatan yang dilakukan oleh siswa dalam kegiatan pembelajaran yang dilakukan di kelas. Dalam pembelajaran bahasa Indonesia, pembelajaran menyusun teks hasil laporan observasi ini menjadi sangat penting karena dalam pelaksanaan pembelajaran, siswa dilatih untuk menyusun hasil pengamatan yang telah dilakukan dalam bentuk tulisan dengan menggunakan bahasa Indonesia dengan baik dan bena

Model pembelajaran yang dianggap tepat untuk menjawab persoalan itu adalah model investigasi sosial. Model ini merupakan hasil adaptasi dari kompilasi model inkuiri sosial, kolaborasi, dan investigasi [2]. Suatu model yang cocok untuk penelaahan gejalagejala sosial serta memungkinkan pembelajaran mengenalkan tentang kearifan lokal serta berorientasi pada pengalaman siswa adalah model inkuiri sosial.

Desain model ini didasari oleh teori model pembelajaran langsung, pembelajaran kooperatif, pembelajaran berdasarkan masalah, pembelajaran kontekstual, model diskusi kelas, dan sistem penilaian portofolio model inovatif-progresif [3]. Perangkat yang dikembangkan terdiri atas (1) silabus, (2) rencana pembelajaran, (3) lembar kegiatan siswa, (3) buku ajar siswa, dan (4) tes hasil belajar. Perangkat tersebut dilengkapi dengan instrumen pembelajaran berupa (1) pengamatan keterlaksanaan rencana pelajaran, (2) lembar pengamatan aktivitas siswa, dan (3) respon siswa. Desain model yang dikembangkan itu dilengkapi juga dengan CD pembelajaran.

Berdasarkan paparan itu dapat disimpulkan bahwa model investigasi sosial merupakan model pembelajaran yang menitiberatkan pada kerja sama antarsiswa dalam penelaahan masalah-masalah sosial yang berada di lingkungan sekitar yang berkonteks kearifan lokal. Melalui model ini, siswa tidak hanya memiliki kemampuan kognitif, psikomotor, dan afektif saja, tetapi juga memiliki karakter positif dalam rangka membangun jati diri bangsa.

Model pembelajaran yang dikembangkan dalam penelitian ini berupa panduan pengembangan model investigasi sosial pada pembelajaran menulis teks laporan hasil observasi berkonteks kearifan lokal. Panduan pengembangan meliputi materi ajar, silabus, rencana pembelajaran, evaluasi, dan pembelajaran. Panduan ini diharapkan menjadi fasilitas guru bahasa Indonesia dalam mengimplementasikan model investigasi sosial pada pembelajaran menulis teks laporan hasil observasi berkonteks kearifan lokal.

Studi eksperimen dilakukan dengan judul Pengembangan Buku Pengayaan Menulis Teks Prosedur Kompleks yang Bermuatan Nilai-Nilai Kewirausahaan [4]. Hasil akhir penelitian tersebut yaitu mengidentifikasi keefektifan antara penggunaan buku pengayaan yang sudah dikembangkan dengan pembelajaran konvensional. Berdasarkan hasil pretes dan postes menunjukan bahwa kelas yang menggunakan buku pengayaan tersebut lebih efektif dibandingkan kelas yang tidak menggunakan buku tersebut. 
Studi eksperimen kuasi juga ada dalam penelitian yang berjudul Keefektifan Pendekatan Proses dan Pendekatan Genre Terhadap Kemampuan Menulis Karangan Argumentasi Siswa SMA [5]. Hasil temuan dalam penelitian tersebut dapat disimpulkan bahwa pendekatan genre lebih efektif dibandingkan dengan pendekatan proses dan pendekatan konvensional dalam peningkatan kompetensi menulis karangan argumentasi siswa SMA kelas $\mathrm{X}$ Kabupaten Banyumas dengan masing-masing skor signifikan $(\mathrm{p})<$ taraf signifikasi yang telah ditentukan sebesar 0,05 .

Judul penelitian Development of Interactive Teaching material of Semantic Course Based on Local Wisdom of Brebes juga termasuk dalam penelitian mix metodh yang berasal dan pengembangan dan eksperimen [6]. Dalam penelitian tersebut terdapat penelitian lanjutan yaitu Keefektifan Penggunaan Bahan Ajar Interaktif yang Berbasis Kearifan Lokal Brebes dalam Mata Kuliah Semantik [7]. Hasil penelitian ini menyatakan bahwa adanya perbedaan yang signifikan hasil pretes dan postes pada mahasiswa PBSI UMUS dengan menggunakan bahan ajar interaktif berbasis kearifan local Brebes. Sehingga dapat disimpulkan bahwa bahan ajar efektif diterapkan dalam perkuliahan semantik.

Pengembangan media pembelajaran untuk meningkatkan kompetensi menulis dengan judul penelitiannya Pengembangan pembelajaran Berbasis Web untuk Meningkatkan Kemampuan Menulis Kreatif Mahasiswa PGSD [8]. Simpulan dari hasil pengembangannya membuktikan bahwa pembelajaran berbasis web dinyatakan layak digunakan dalam proses pembelajaran. Hal ini dapat dilihat dari hasil perbedaan rata-rata yang signifikan antara dua kelompok sebelum dan sesudah diberikan perlakuan.

Penelitian tentang eksperimen dalam objek menulis juga dilakukan dengan judul Keefektifan Metode Time Token Arends dan Mind Mapping dalam Menulis Teks Eksposisi [9]. Penelitian tersebut menghasilkan simpulan bahwa hasil belajar menggunakan metode time token arend sebesar 82,56. Sedangkan hasil rata-rata menggunakan metode mind mapping sebesar 76,54. Hasil statistik bahwa diperoleh $\mathrm{t}_{\text {hitung }} 2.930>\mathrm{t}_{\text {tabel }} 1.714$. Jadi dapat disimpulkan bahwa metode time token arend lebih efektif disbanding metode mind mapping.

Penelitian pengembangan selanjutnya dengan judul penelitian Pengembangan Bahan Ajar IPA Berbasis Learning untuk Siswa kelas V Sekolah Dasar [10]. Hasil penelitiannya dipaparkan bahwa hasil tes keterbacaan dari bahan ajar menunjukan bahwa kriteria keterbacaan mudah dipahami dengan nilai rata-rata siswa $88 \%$. Secara umum dapat disimpulkan bahwa Pengembangan Bahan Ajar Tema Lingkungan Sahabat Kita di Kelas V Sekolah Dasar Berbasis Problem Based Learning dinyatakan valid.

Penelitian pengembangan selanjutnya berjudul Pengembangan Modul Praktikum IPA Berbasis Kurikulum 2013 untuk Mahasiswa Pendidkkan Guru Sekolah Dasar [11]. Hasil penelitian tersebut menunjukkan bahwa modul praktikum yang dikembangkan layak dan efektif untuk digunakan. Dibuktikan dengan adanya peningkatan dan perbedaan rata-rata keterampilan proses dan keaktifan mahasiswa yang signifikan setelah perlakuan.

\section{METODE PENELITIAN}

Dalam penelitian ini digunakan pendekatan research and development (R\&D) atau penelitian pengembangan menjelaskan bahwa penelitian pengembangan merupakan suatu metode penelitian yang digunakan untuk menghasilkan produk tertentu dan menguji keefektifan produk tersebut [12]. Produk yang dimaksudkan di sini adalah model investigasi sosial pada pembelajaran menulis teks laporan hasil observasi berkonteks kearifan lokal.

Data yang diperlukan dalam pengembangan model investigasi sosial pada pembelajaran menulis teks laporan hasil observasi berkonteks kearifan lokal untuk peserta didik kelas VIII SMP/MTS yaitu 1) data skor kebutuhan pengembangan model investigasi sosial pada pembelajaran menulis teks laporan hasil observasi berkonteks kearifan lokal menurut guru dan peserta didik, 2) data skor penilaian produk model investigasi sosial pada pembelajaran menulis teks laporan hasil observasi berkonteks kearifan lokal oleh validator yaitu guru dan ahli, 3) data 
skor akhir data uji keefektifan model investigasi sosial pada pembelajaran menulis teks laporan hasil observasi berkonteks kearifan lokal.

Tahap observasi dilakukan sebagai tahap awal dalam penelitian dan pengembangan. Tahap observasi dilakukan dengan tujuan untuk mengetahui proses pembelajaran menulis teks laporan hasil observasi. Pada tahap observasi peneliti menggunakan angket kebutuhan sebagai teknik pengumpulan data awal.

Penelitian dilakukan di tiga sekolah yang berbeda. Ketiga sekolah tersebut yaitu SMP N 1 Ketanggungan, SMP N 2 Banjarharjo, dan MTS Subulul Ikhsan Kersana. Dari hasil pengambilan sampel pada masing-masing sekolah terpilih kelas VIII A dan VIII B di SMP N 1 Ketanggungan, Kelas VIII C, dan VIII D di SMP N 2 banjarharjo, dan Kelas VIII A dan VIII B di MTS Subulul Ikhsan Kersana sebagai kelas penelitian. Ketiga sekolah tersebut belum pernah diteliti atau belum pernah digunakan untuk penelitian pengembangan.

Instrumen yang dikembangkan pada tahap ini terdiri atas (1) instrumen kebutuhan model investigasi sosial pada pembelajaran menulis teks laporan hasil observasi berkonteks kearifan lokal pada siswa kelas VIII SMP/MTS, (2) instrument validasi model investigasi sosial pada pembelajaran menulis teks laporan hasil observasi pada siswa kelas VIII SMP/MTS, (3) Instrumen uji kelas terbatas model investigasi sosial pada pembelajaran menulis teks laporan hasil observasi pada siswa kelas VIII SMP/MTS. .

Untuk memperoleh gambaran umum tentang instrumen yang digunakan dalam penelitian ini dapat dilihat pada tabel berikut.

Tabel 1 Kisi-Kisi Instrumen Penelitian

\begin{tabular}{|c|l|l|l|}
\hline No. & \multicolumn{1}{|c|}{ Aspek } & \multicolumn{1}{c|}{ Sumber } & \multicolumn{1}{c|}{ Instrument } \\
\hline 1. & $\begin{array}{l}\text { Kebutuhan draf model } \\
\text { investigasi sosial mata } \\
\text { pelajaran menulis teks } \\
\text { laporan hasil observasi } \\
\text { berkonteks kearifan lokal }\end{array}$ & $\begin{array}{l}\text { Guru dan Siswa: } \\
\text { 1. SMP N 1 } \\
\text { ketanggungan } \\
\text { 2. SMP N 2 Banjarharjo } \\
\text { 3TS Subul Ikhsan } \\
\text { Kersana }\end{array}$ & $\begin{array}{l}\text { Tes tertulis berupa } \\
\text { angket kebutuhan } \\
\text { guru dan siswa }\end{array}$ \\
\hline 2. & $\begin{array}{l}\text { Validasi draf model } \\
\text { investigasi sosial mata } \\
\text { pelajaran menulis teks } \\
\text { laporan hasil observasi } \\
\text { berkonteks kearifan lokal }\end{array}$ & $\begin{array}{l}\text { Dosen ahli model } \\
\text { pembelajaran menulis }\end{array}$ & Angket uji validasi \\
\hline 3. & $\begin{array}{l}\text { Uji keefektifan model } \\
\text { investigasi sosial mata } \\
\text { pelajaran menulis teks } \\
\text { laporan hasil observasi } \\
\text { berkonteks kearifan local }\end{array}$ & $\begin{array}{l}\text { Siswa SMP N 1 } \\
\text { Ketanggungan Brebes }\end{array}$ & $\begin{array}{l}\text { Pedoman penilaian } \\
\text { mata pelajaran } \\
\text { menulis teks laporan } \\
\text { hasil observasi }\end{array}$ \\
\hline
\end{tabular}

Teknik analisis data kebutuhan dilakukan dari hasil angket yang diisi oleh guru mata pelajaran Bahasa Indonesia dan peserta didik kelas VIII di SMP $\mathrm{N} 1$ Ketanggungan Brebes, SMP N 2 banjarharjo Brebes, dan MTS Subulul Ikhsan Kersana Brebes yang dipilih secara random. Dari hasil analisis yang dilakukan akan digunakan untuk pembuatan draf model investigasi sosial untuk pembelajaran menulis teks laporan hasil observasi berkonteks kearifan lokal. Teknik uji validitas produk menggunakan jenis validitas isi yang menggunakan bantuan ahli dibidang model pembelajaran untuk memberikan penilaian, evaluasi, dan analisis terhadap draf yang selanjutnya akan digunakan sebagai dasar pijakan untuk membuat model pembelajaran investigasi sosial.

HASIL DAN PEMBAHASAN 
Hasil penelitian yang dipapakan dalam bab ini, yaitu paparan hasil analisis kebutuhan sisa dan guru, paparan hasil penilaian terhadap produk dari ahli, paparan hasil uji coba produk, dan tampilan produk yang berupa model investigasi sosial pada pembelajaran menulis teks laporan hasil observasi berkonteks kearifan lokal untuk kelas VIII SMP?MTS.

Model yang dihasilkan akan diaplikasikan dalam pembelajaran menulis teks laporan hasil observasi kelas VIII baik disemester gasal ataupun semester genap berdasarkan analisis kebutuhan model dan karakteristik model pembelajaran. Analisis kebutuhan diterapkan pada siswa dan guru. Dua subjek tersebut dipilih dengan maksud untuk mengetahui berbagai keperluan materi pembelajaran menulis karangan yang dibutuhkan selama pembelajaran di kelas VIII. Pengambilan data menggunakan sistem angket. Hasil dari angket yang telah terisi oleh siswa dan guru digunakan sebagai bahan acuan dalam pengembangan model pembelajaran menulis teks laporan hasil observasi berkonteks kearifan lokal. Selain itu, hasil analisis kondisi model pembelajaran yang ada menjadi acuan guna menyempurnakan model pembelajaran. Berikut ini paparan hasil analisis kebutuhan sisa dan guru.

Peserta didik yang digunakan sebagai sumber data adalah siswa SMP kelas VIII dari tiga sekolah yang berbeda. Ketiga sekolah yang terpilih adalah SMA N 1 Ketanggungan, SMP N 2 banjarharjo, dan MTS Subulul Ikhsan Kersana. Dari ketiga sekolah tersebut akan diwakili oleh peserta didik kelas VIII dan masing-masing sekolah akan diwakili oleh 2 kelas. SMP N 1 Ketanggungan akan diwakili oleh kelas VIII A dan VIII B. SMP N 2 Banjarharjo diwakili oleh kelas VIII C dan VIII D. Dan MTS Subulul Ikhsan akan diwakili oleh kelas VIII A dan VIII B Jumlah siswa yang mewakili di SMP N 1 Ketanggungan adalah 60 siswa, di SMP N 2 Banjarharjo adalah 60 siswa,dan di MTS Subulul Ikhsan Kersana 60 siswa Total keseluruhan responden untuk kebutuhan siswa adalah 180.

Analisis kebutuhan peserta didik terhadap model investigasi sosial pembelajaran menulis teks laporan hasil observasi berkonteks kearifan lokal terdiri dari sebelas aspek aspek, yaitu (1) pendapat peserta didik terhadap kompetensi menulis teks laporan hasil observasi penting dikuasai siswa, (2) materi teks laporan hasil observasi yang diberikan guru berkaitan dengan budaya (kebiasaan, tata cara) yang berlaku di lingkungan siswa, (3) pendapat peserta didik terhadap perlakuan guru terhadap siswa sama tanpa memandang etnis, suku, gender, (4) pendapat peserta didik terhadap contoh teks laporan observasi yang dibuat benar-benar hasil pekerjaan sendiri, (5) pendapat peserta didik terhadap hasil pekerjaannya, (6) pendapat peserta didik terhadap hasil presentasi pekerjaannya, (7) pendapat peserta didik tentang menilai/mengomentari hasil pekerjaan teman, (8) pendapat peserta didik terhadap hasil refleksi pembelajaran, (9) pendapat peserta didik terhapa tugas rumah kepada siswa secara berkelompok, (10) pendapat peserta didik terhadap hasil pekerjaan siswa sesuai dengan kemampuan tanpa melihat latar belakang siswa, dan (11) pendapat peserta didik terhadap guru yang selalu memberikan bimbingan terhadap kesulitan siswa.

Analisis kebutuhan peserta didik terhadap materi kearifan lokal terdiri dari tujuh aspek,yaitu,(1) keterkaitan materi pelajaran dengan pengenalan kearifan lokal daerah sekitar, (2) keterkaitan buku-buku yang mengenalkan kearifan budaya, (3) keterkaitan penugasan guru kepada siswa tentang menulis kebiasaan/tata cara yang ada di keluarga, di sekolah, atau di masyarakat, (4) keterkaitan penugasanguru kepada siswa untuk menceritakan kearifan lokal di daerah masing-masing, (5) keterkaitan materi dengan pengenalan budaya, (6) perlunya pemahaman budaya yang ada di lingkungan keluarga, sekolah, dan masyarakat, (7) perlunya menghargai budaya teman yang berbeda etnik/agama/tingkat sosial, (8) perlunya menemukan ada kebiasaan dan budaya teman yang sangat berlainan dengan kebiasaan dan budaya masingmasing.

Pendapat pesrta didik terhadap model investigasi sosial pembelajaran menulis teks laporan hasil onservasi berkonteks kearifan lokal yang selama ini diperoleh digunakan peneliti untuk menganalisis kebutuhan model pembelajaran untuk siswa SMP kelas VIII tersebar di semester gasal. Jumlah responden yang memilih point a (sangat setuju) sebanyak 150 siswa. Jumlah peserta didik yang memilih poin b (setuju) sebanyak 20 siswa, dan peserta didik yang 
memilih point c (biasa) sebanyak 10 siswa. Dari hasil tersebut membuktikan bahwa peserta didik menganggap materi tersebut sangat penting dan perlu untuk dipelajari selama 1 semester.

Analisis terhadap sumber belajar peserta didik dilakukan dengan tujuan untuk mengetahui berbagai macam sumber bahan belajar yang selalu guru dan siswa gunakan. Analisis sumber belajar dilakukan sebagai acuan bagi peneliti untuk menggunakan dan mengembangkan sumber belajar yang lebih efektif dan kreatif dalam pembelajaran menulis teks laporan hasil observasi berkonteks kearifan lokal. Selain itu, analisis terhadap sumber belajar dilakukan guna mengetahui kebutuhan peserta didik terhadap sumber belajar yang dapat digunakan selama pembelajaran menulis teks laporan hasil observasi berkonteks kearifan lokal.

Analisis kebutuhan guru terhadap pemahaman guru tentang kearifan lokal terdiri dari empat aspek,yaitu, (1)guru mengaitkan pembelajaran dengan berbagai masalah sosial budaya yang ada di masyarakat lingkungan siswa, (2) guru merasakan bahwa siswa memiliki latar belakang etnik, budaya, dan bahasa yang berbeda, (3)guru merasakan bahwa siswa memiliki latar belakang berbeda, tetapi guru menganggap hubungan antarsiswa terjalin harmonis, (4) Guru memiliki kepedulian terhadap kegiatan esktrakurikuler bermuatan kearifan lokal .

Analisis kebutuhan guru terhadap kurikulum terdiri dari tiga aspek, yaitu, (1) Materi teks laporan hasil observasi yang tertuang dalam kurikulum sangat penting/penting dikuasi siswa, (2) Indikator yang dikembangkan mencakup aspek kognitif, psikomotor, dan afektif, (3) Pengembangan kompetensi petunjuk ke arah pengenalan budaya, kebiasaan, sosial, dsb.

Analisis kebutuhan guru terhadap pembelajaran menulis pada aspek materi terdiri dari tiga aspek, yaitu (1) Sumber materi yang dipersiapkan guru berasal dari buku teks, (2) Dalam mengawali pembelajaran, guru mengaitkan materi dengan pengalaman ataupun reaitas kehidupan sosial budaya siswa, (3) Guru menyampaikan contoh teks hasil observasi yang berkenaan dengan kearifan budaya sekitar. Analisis pada aspek penilaian terdiri dari dua aspek yaitu, (1) Instrumen soal menulis teks laporan hasil observasi yang dibuat guru berkenaan dengan budaya, adat, atau kebiasaan siswa, (2) Teknik penilaian yang dilakukan guru berupa tes tertulis. Analisis pada aspek interaksi guru dan siswa terdiri atas tujuh aspek yaitu (1) Guru meminta siswa untuk menyampaikan pengalaman yang berkenaan dengan masalah-masalah sosial budaya, (2) Guru memperlakukan siswa secara sama dengan tidak memandang perbedaan etnis, suku, gender, agama, bahasa, budaya, (3) Guru lebih mengembangkan kemampuan berpikir daripada hafalan, (4) Guru meminta siswa untuk mempresentasikan/ melisankan hasil pekerjaannya, (5) Guru meminta siswa untuk menilai atau mengomentari hasil pekerjaan siswa, (6) Guru meminta siswa untuk merefleksi pembelajaran, (7) Guru meminta siswa untuk melaksanakan tugas rumah secara berkelompok.

Dari responden yang berjumlah 15 guru dikemukakan bahwa, sebanyak 5 (33\%) guru mengorganisasi siswa untuk belajar secara individu dan kelompok serta 1 orang guru ( $6 \%$ ) mengorganisasi siswa secara individu dan berpasangan, 5 orang guru (33\%) mengorganisasi siswa hanya secara berkelompok, 2 guru (13\%) mengorganisasi siswa hanya secara individu, dan 2 orang guru (13\%) mengorganisasi siswa hanya secara berpasangan. Dapat pula dijelaskan bahwa pengorganisasian siswa secara berkelompok telah dilakukan oleh 10 orang guru (67\%), pengororganisasian siswa secara berpasangan dilakukan 3 orang guru (20\%). Kondisi ini dapat diinterpretasikan bahwa 13 orang guru (87\%) telah mengembangkan kerja sama antarsiswa. Hal ini berarti guru membutuhkan suatu model pembelajaran yang dapat mengakomodasi belajar secara kelompok.

Berdasarkan hasil uji coba untuk mengetahui tingkat keefektifan model investigasi sosial pembelajaran menulis teks laporan hasil observasi berkonteks kearifan lokal dilakukanlah uji beda yang diterapkan pada siswa SMP kelas VIII di SMP N 1 Ketanggungan, SMP N 2 Banjarharjo, dan MTS Subulul Ikhsan Kersana. Hasil uji keefektifan tersebut menunjukkan bahwa model tersebut terbukti efektif untuk 
digunakan dalam pembelajaran menulis teks laporan hasil observasi. Hal tersebut dibuktikan dengan skor-t pada hasil uji beda yang diperoleh pada kelas-kelas yang digunakan sebagai tempat pengambilan data. Pada SMP N 1 Ketanggungan skor t yang dihasilkan sebesar 10,653, skor t hitung pada SMP N 2 Banjarharjo menghasilkan skor sebesar 7,785, dan skor t hitung pada MTS Subulul Ikhsan Kersana sebesar 10,986 . Skor t hitung yang dihasilkan lebih besar dibandingkan skor t tabel dengan signifikasi sebesar 0,05. Oleh karena itu, model ini cukup relevan untuk digunakan sebagai model pembelajaran bagi guru dan peserta didik selama pembelajaran menulis teks laporan hasil observasi.

\section{KESIMPULAN}

Berdasarkan hasil pengembangan model yang telah dilakukan dan hasil uji keefektifan yang telah diuji cobakan pada enam kelas menunjukkan bahwa model investigasi sosial pembelajaran menulis teks laporan hasil observasi berkonteks kearifan lokal ini efektif digunakan sebagai model pembelajaran bagi guru dan peserta didik selama pembelajaran. Dengan adanya model ini guru dan peserta didik akan terbantu dalam pembelajaran dan juga strategi pembelajaran yang dapat sebagai pijakan utama.

\section{DAFTAR PUSTAKA}

[1] Parera, J.D, Petunjuk Guru Pintar Berbahasa Indonesia Sekolah Lanjutan Tingkat Pertama, 1999, Balai Pustaka, Jakarta.

[2] Winataputra, Udin S, Model-model Pembelajaran Inovatif, 2001, PAU-PPAI UT, Jakarta.

[3] Trianto, Model Pembelajaran Terpadu dalam Teori dan Praktek, 2009, Prestasi Pustaka Publisher, Jakarta.

[4] Kurniawan, Prasetyo Yuli, dan Subyantoro, "Pengembangan Buku Pengayaan Menulis Teks Prosedur Kompleks yang Bemuatan Nilai-Nilai Kewirausahaan”. Jurnal Seloka., vol. 5, no. 1, pp. $71-80,2016$, [online]. Available:

https://journal.unnes.ac.id/sju/index.php/seloka/article/view/12753/6924

[5] Apryliana, Agnes, "Keefektifan Pendekatan Proses dan Pendekatan Genre Terhadap Kemampuan Menulis Karangan Argumentasi Siswa SMA", Diksi., Vol. 25 No. 1 2017, [online]. Available:

https://journal.uny.ac.id/index.php/diksi/article/view/16181

[6] Kurniawan, Prasetyo Yuli, "Development of Interactive Teaching material of Semantic Course Based on Local Wisdom of Brebes”, Jurnal Seloka.Vol.7, no.3, pp.229-235, 2018, , [online]. Available:

https://journal.unnes.ac.id/sju/index.php/seloka/article/view/27013/11830

[7] Kurniawan, Prasetyo Yuli, 2019, "Keefektifan Penggunaan Bahan Ajar Interaktif Yang Berbasis Kearifan Lokal Brebes Dalam Mata Kuliah Semanik". Bahastra. Jurnal Pendidikan Bahasa dan Sastra Indonesia. Vol. 3, No. 2, 2019. Available: https://journal.uisu.ac.id/index.php/Bahastra/article/view/1159 
[8] Mumpuni Atikah dan Pratiwiningsih L, "The Development of a Web Based learning to Improve of a Creative Writing Ability of PGSD Students". Cakrawala Pendidikan, [online]. Available:

https://journal.uny.ac.id/index.php/cp/article/view/20009

[9] Ernawati, Septi Dwi, dkk, "Keefektifan Metode Time TOkend Arends dan Mind Mapping dalam Menulis Teks Eksposisi", Jurnal Ilmiah Semantika, vol. 1, no. 1, pp. 55 62, 2019, [online]. Available:

http://jurnal.umus.ac.id/index.php/semantika/article/view/82

[10] Nurbaeti, Rizki Umi, "Pengembangan Bahan Ajar IPA Berbasis Problem Based Learning untuk Siswa Kelas V Sekolah Dasar", Cakrawala Pendas, Vol. 5 No.1, 2019, [online]. Available:

https://journal.unma.ac.id/index.php/CP/article/view/1233

[11] Nurbaeti, Rizki Umi, "Pengembangan Modul Praktikum IPA Berbasis Kurikulum 2013 untuk Mahasiswa Pendidikan Guru Sekolah Dasar", Elementaria Edukasia, Vol. 3 No.1, 2020, [online]. Available:

https://journal.unma.ac.id/index.php/jee/article/view/2115

[12] Sugiyono, Metode Penelitian Kuantitatif Kualitatif dan $R \& D, 2010$, Alfabeta, Bandung. 